\title{
Innovation in journalism educational programmes at university. A systematic review of educational experiences at Spanish universities
}

\author{
María-del-Carmen García-Galera; Manuel Martínez-Nicolás; Mercedes \\ Del-Hoyo-Hurtado
}

Nota: Este artículo se puede leer en español en:

http://www.elprofesionaldelainformacion.com/contenidos/2020/may/garcia-martinez-del-hoyo_es.pdf

How to cite this article:

García-Galera, María-del-Carmen; Martínez-Nicolás, Manuel; Del-Hoyo-Hurtado, Mercedes (2021). "Innovation in journalism educational programmes at university. A systematic review of educational experiences at Spanish universities". Profesional de la información, v. 30, n. 3, e300307.

https://doi.org/10.3145/epi.2021.may.07

Manuscript received on $24^{\text {th }}$ November 2020 Accepted on $23^{\text {rd }}$ February 2021

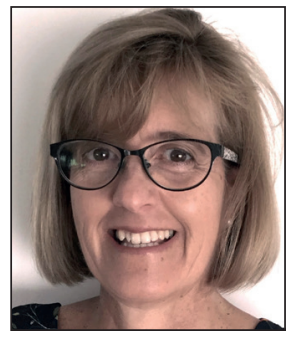

\section{María-del-Carmen García-Galera https://orcid.org/0000-0001-6211-2700 \\ Universidad Rey Juan Carlos \\ Facultad de Ciencias de la Comunicación Camino del Molino, 5 28943 Fuenlabrada (Madrid), Spain carmen.garcia@urjc.es}

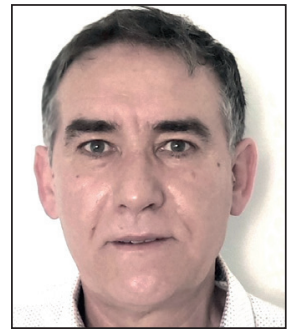

Manuel Martínez-Nicolás $\triangle$ https://orcid.org/0000-0002-3949-2351 Universidad Rey Juan Carlos Facultad de Ciencias de la Comunicación Camino del Molino, 5 28943 Fuenlabrada (Madrid), Spain manuel.martinez.nicolas@urjc.es

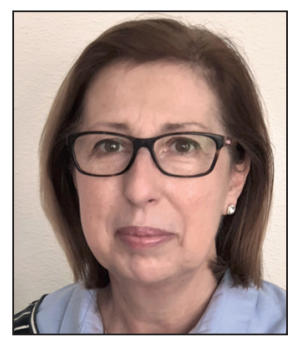

Mercedes Del-Hoyo-Hurtado https://orcid.org/0000-0001-6533-4771

Universidad Rey Juan Carlos

Facultad de Ciencias de la Comunicación

Camino del Molino, 5

28943 Fuenlabrada (Madrid), Spain

mercedes.hoyo@urjc.es

\begin{abstract}
The journalism being taught at universities in Spain is undergoing intensive changes as a result of the dual pressure exerted by the impact of digitisation in two specific aspects. The first is the journalistic system itself (business models, professional routines, information consumption, etc.). The second aspect involves the teaching guidelines established as a result of the implementation of the European Higher Education Area (EHEA). Focusing on the latter issue, the current debate regarding the orientation of journalistic education is calling for this aspect not to be relegated or limited to training in technical skills, which are constantly being renewed by technological developments of the digital environment. On the contrary, journalism education must also take into account other skills that foster the achievement of critical thinking, which is fundamental for the exercise of the journalistic profession. However, in the face of an increasingly digitised, competitive labour market, journalism studies and their training programmes also have a duty to provide the skills and competencies demanded by this market. In this paper, we have conducted a systematic review of some of the experiences of innovative teaching that have been successfully carried out in Journalism degrees taught in Spain for this purpose (service-learning, project-based learning, content curation, and edublogs, among others). These experiences reflect the involvement of university professors in providing comprehensive education for future journalists, with a strong emphasis on the intensive use of the digital resources currently available.
\end{abstract}

\section{Keywords}

Journalism; University training programs; Teaching; Innovation; Digitisation; Active learning; Systematic review; Technology; EHEA; Digital tools. 
Financing

This work is part of the project entitled Empleabilidad y emprendimiento en comunicación en el contexto digital: demandas del mercado de trabajo, oferta formativa universitaria y experiencia laboral de los graduados (Employability and entrepreneurship in communication in the digital context: labour market demands, university educational offering, and work experience of the graduates), funded by the Spanish State Plan of $R+D+i$ (PID2019-106299GB-I00) (AEI/10.13039/501100011033).

\section{Introduction}

The changes being driven by digitisation in all areas of life in contemporary developed societies, including the economy, education, work, leisure, interpersonal relationships, consumption, politics and more, have had a decisive impact on the communication sector, and especially on journalism. It suffices to compare the expectations of just two decades ago (Pavlik, 2001) with the future horizon already in view (Newman, 2020) in order to realise that the intensity of these changes has exceeded all forecasts, radically transforming all facets of journalism, from the business model of companies to the way in which the work in newsrooms is organised, and from the techniques and formats for reporting the news to the relationships with users of such information.

If there is one thing that characterises the digital environment, it is the tendency toward unrestrained innovation, subjecting the activities of this domain to permanent tension in order to adapt to new developments and benefit from constantly updated options. In this dialectic that pursues a continually shifting horizon, journalism has been committed from the very moment it was compelled to migrate to the digital space a quarter of a century ago (Salaverría, 2019). The latest episode in this compulsive movement of adaptation and renewal is the so-called high-tech journalism, which calls on the journalistic discipline to explore and incorporate the opportunities offered by emerging technologies into its reporting, such as artificial intelligence, augmented reality, immersive environments, drones, blockchain, and 5G (Salaverría, 2015; López-Hidalgo, 2016; Pérez-Seijo; Gutiérrez-Caneda; López-García, 2020). Although the path that journalism must now take is not free from serious risks (Murcia-Verdú; Ufarte-Ruiz, 2019), and the experiences and training of professionals are not only at the very beginning, but are undertaken with reluctance and suspicion (Murcia-Verdú; Ufarte-Ruiz, 2019; Ufarte-Ruiz; Calvo-Rubio; Murcia-Verdú, 2020), everything seems to point to the fact that this high-tech journalism will be "the journalism that narrates the future" (López-Hidalgo, 2016), and it might even be the type of journalism that is most influential in the future as well.

The challenges and tensions faced by the exercise of journalism in these conditions have been transferred to the field of university education, also impelled in the last two decades to constantly update its knowledge and reflection on the skills and professional profiles demanded by a labour market with its constantly shifting demands (Sánchez-García; Campos-Domínguez; Berrocal-Gonzalo, 2015; López-García; Rodríguez-Vázquez; Pereira-Fariña, 2017; Rodríguez-Pallarés; Segado-Boj, 2020). However, the horizon here is also shifting at a pace that is unattainable for university curricula and ordinary teaching practice, generating a kind of "pedagogical frustration" that arises from realising the following:

"When companies demand professionals with the skills to create multiplatform and 2.0 content, the theoretical-practical knowledge related to the assimilation of hypertextual and multimedia narratives continues to channel our instructional efforts toward the pedagogy of cyber journalism to a large extent" (Fernandes-Teixeira; Larrondo, 2019, p. 5).

Moreover, it seems that this frustration will continue to grow with the new educational demands posed by the emergence of high-tech journalism. In a recent study (Ufarte-Ruiz; Calvo-Rubio; Murcia-Verdú, 2020), these authors analysed 768 subjects from 17 Journalism curricula offered at Spanish universities to determine the presence of topics on artificial intelligence, drones, mobile journalism, immersive environments, and virtual reality, and noted that the implementation of high-tech journalism teaching is still scarce.

"Of the 17 curricula analysed, only 10 have subjects that totally or partially dedicate some content or modules to the study of this discipline",

and warn that

"there is still no consensus when it comes to deciding which subjects should be paramount in dealing with issues related to high technology in the field of journalism" (Ufarte-Ruiz; Calvo-Rubio; Murcia-Verdú, 2020, pp. 56 y 57).

In any case, the debate on the direction taken by university journalism teaching in the current context insists on the appropriateness of maintaining a balance between training in technical skills that need to be constantly updated due to the continual development and renewal of
University curricula must be continuously updated to meet the demands of a labour market with constantly changing requirements 
digital technologies, and the teaching of fundamental competencies for the exercise of the journalistic profession (Huang et al., 2006; Sánchez-García; Marinho, 2016; Ufarte-Ruiz; Calvo-Rubio; Murcia-Verdú, 2020). As pointed out by Huang et al. (2006, p. 254-255):

"Critical thinking is the cornerstone of journalistic education, although technological subjects should also be given the consideration they deserve... An ideal curriculum should balance the weight of subjects aimed at acquiring technical skills and those aimed at training in critical thinking, with a bias toward the latter... Ultimately, technology subjects should not dominate the education of journalism students, and technology should not be taught for its own sake, as it must serve the purpose of carrying out quality journalism".

This reflection provides a reasonable perspective for innovative pedagogical initiatives in journalism education, or at least points out what should be influential in an appropriate, well-directed undertaking in pedagogical innovation. Therefore, the idea of teaching innovation in the field of journalism cannot be reduced or restricted to the incorporation of technology and its associated skills into the instruction of students, but must also remain open to teaching practices aimed at training future journalists in the concept of "critical thinking, as summarised by Huang et al. (2006)". With the aim of highlighting these practices, this paper reviews some of the experiences implemented in recent years by the teaching staff of journalism degrees taught at Spanish universities.

\section{University education and active learning in the EHEA}

Implementation of the guidelines set out by the European Higher Education Area (EHEA) in the field of teaching has posed a major challenge for the teaching staff of Spanish universities, who are faced with new ways of teaching, transmitting knowledge, and evaluating students.

With the aim of making it easier for university students to acquire and retain knowledge that is useful for their professional lives, a multitude of innovative teaching-learning experiences have emerged (Centre for Educational Research and Innovation, 2016; Ramírez-Ramírez; Ramírez-Montoya, 2018). These experiences have been analysed and evaluated through ad hoc studies, but also through professors sharing their personal experiences and suggestions with the educational community (Lara; García-Castillo; Bueno-Doral, 2018).

Since implementation of the EHEA in Spain in 2007, there have been hundreds of conferences, seminars, congresses and monographs of specialised scientific journals devoted to all initiatives that can be included under the umbrella term of "teaching innovation" (Llorens; Bonet, 2016; Martínez-Nicolás, 2016). One of the elements common to nearly all of them is that they point to the student as the lead player in the new educational scenario based on active learning, as opposed to traditional education based on the professor's teaching. The student must take an active and participatory role in the process of his or her own education (Espinosa et al. 2006). For Gonzálvez-Vallés (2014), citing Mauri, Coll and Onrubia (2007), the EHEA is based on three principles that should inspire teaching activity:

- the promotion of educational initiatives that emphasise the students' own work;

- the development of collaborative learning along with a new perception of the professor as a guide or adviser; and

- the self-directed generation of knowledge by students.

It is now a question of designing activities centred on the student, in which the student is capable of engaging in self-learning that leads to the attainment of meaningful knowledge. This new vision has arisen as a reaction to the previous educational paradigm, to which the evidence now points as being ineffective in the development of knowledge and competencies in students (Peinado et al., 2013). At the present time, the prediction that the illiterate individual is not the one who does not know how to read, but the one who does not know how to learn, is being fulfilled (Lee, 2013).

In addition to active learning or learning based on experience (Shuell, 1986), cooperative learning is also present at this stage (Johnson; Johnson; Holubec, 1999), which requires the professor to organise the proposed activities effectively and offer the necessary guidelines so that the essential elements are provided in order for this cooperation among students to be productive (Peinado et al., 2013).

The main tools that have emerged from advancements in information and communication technologies have fostered teaching innovation at all educational levels, including universities, some examples of which include the following: the development of wikis, blogs, podcasts, electronic platforms for subjects, the recording and re-transmission of video lessons, content tagging (folksonomies), the availability of MOOCs, participation in social networks, and so on (Llorens; Bonet, 2016; Cáceres et al., 2019). Even though Llorens and Bonet (2016) state that most experiences in Spain are based on the use of these technologies to develop teaching innovations, García-Retamero (2010) warns of the error in thinking that the mere use of ICT implies educational innovation, which is not the case if one con-
Innovative teaching in journalistic education cannot be reduced to merely instructing students in the uncritical use of technological tools 
tinues to do the same thing with the new technological resources. It is necessary to have a broader, more comprehensive perspective in which the student promotes self-learning and develops his or her critical, creative thinking skills through teamwork, while using new technologies whenever they are necessary.
Nowadays, the aim is to design learner-centred activities in which the student can engage in self-learning that will lead to the acquisition of meaningful knowledge

\section{Technology at the service of learning}

As pointed out by Sánchez-García and Marinho (2016, p. 348),

"the $21^{\text {st }}$ century journalist is already unavoidably digital in the entire information process: search, confirmation, interpretation, and dissemination..."

of news material. These authors carried out a review of the journalism curricula offered by Spanish and Portuguese faculties, concluding that these institutions had taken advantage of the European educational integration in order to increase training in digital journalism with an approach that was more practical and technical than the teaching had provided previously, including content that was digital, multimedia, or related to new technology.

However, as part of the student learning process, technology must be considered not only a learning objective (i.e., as part of the teaching content), but also as a tool for learning (as a teaching resource). As explained by De-la-lglesia-ViIlasol (2019), when viewed as a tool for student education, the use of ICT in the classroom has gone from a two-way process of professor to student (education 1.0, static, without interaction) to free access by the student to content and resources (education 2. 0 , more social, characterised by exchange) in a self-directed process where students build their learning and knowledge by developing content for individual or collective use under the educator's supervision (education 3.0, designed on a more semantic, personalised Web in the ways of accessing information). The last step to be taken, education 4.0, has a differentiating element, which is the predominant role of the student, and it involves integration and multidirectional cooperation between the various actors (professors, students, content and tools developers, programmers, etc.), and opportunities to build knowledge through the creation of content.

Current teaching practice seems to place special emphasis on the use of digital technologies inside and outside the classroom as a vehicle for generating and transmitting knowledge, or as a means of communication, in both cases between professors and students, or among students themselves (virtual campuses, electronic resource platforms, communication media, topic forums, blogs, wikis, simulation platforms/interactive games, augmented reality games, social networks, etc.).

\section{Methodology}

The main objective of this research is to present innovative teaching practice that has tried to incorporate ICT into the educational process, and which have been developed in Journalism Degree programmes in Spain, based on a systematic review of the existing literature regarding experiences of this kind, so that professors can have access to an overview of what has been done so far in teaching innovation, the subjects involved, and the results. The hypothesis of the study states that the need for change brought about by the EHEA in teaching approaches in the classroom was the trigger for implementation of innovation projects by professors, which have received a positive response from students and have had a positive impact on their learning.

Reviews of the scientific literature provide up-to-date knowledge on a given topic and offer the scientific community new lines of research in the field of study in question (Blanco-Alfonso; García-Galera; Tejedor, 2019). In fact, accumulated knowledge is the basis on which new research is developed through a process of refutation, confirmation, or exploration of new approaches that contribute to explaining the phenomena analysed (Guirao-Goris, 2015).

In this context, the one that is gaining ground is the so-called systematic review, or literature review aimed at a variety of objectives, one of the most important of which is to advance the state of the research in any field of Human and Social Science. These reviews provide a rigorous, systematic framework (hence their name) for conducting literature reviews (Codina, 2018).

A systematic review (SR) is work that involves a synthesis of the available evidence in which a quantitative and/or qualitative approach is taken toward primary studies on a given subject in order to summarise the existing information on a particular topic (Manterola et al., 2013). For the study at hand, we have selected the scientific articles published in the Redalyc journal portal on teaching innovation experiences in the Bachelor's Degree Programmes of Journalism at Spanish universities. The selection also took into account the fact that the authors have recorded the results that these innovation activities have had on the competencies, skills and knowledge of the students. Therefore, it is not only a question of describing what the professors

The belief that innovation takes place merely by applying ICT to teaching practice is erroneous, if one continues to do the same old thing with new technological resources 
have accomplished and how they have accomplished it, but also the results they have obtained (Gálvez-de-laCuesta; Esteban-Sánchez; Rivas-Rebaque, 2019). In the search, keywords such as "innovation", "communication", and "degree" were used. Based on the search, the articles registered have been organised into the different models of innovation identified as follows: service-learning, project-based learning, content curation, and collaborative digital tools such as edublogs and immersive virtual environments.

\section{Modalities and experiences of teaching innovation in journalism education}

\subsection{Service-learning (SL)}

Service-learning is a pedagogical method that consists of involving students in educational tasks and activities that can at the same time benefit groups or entities operating in the students' immediate environment, and therefore requires "networking with associations and institutions in the community" (Grupo Aprendizaje-Servicio Unizar, n.d.). In the case of Journalism studies, the service provided by students allows the "other" beneficiaries to obtain public visibility for the activity they carry out, or for the claims and demands they propose, which is why they tend to focus on local organisations with generally limited access to the mainstream media.

According to Llorens and Bonet (2016), one of the most frequently used teaching innovations in Journalism studies in Spain is precisely based on the SL methodology of service-learning (Álvarez-Nobell; Vadillo-Bengoa, 2013; Marta-Lazo; González-Aldea, 2012; González-Aldea; Marta-Lazo, 2015). In actual practice, service-learning initiatives have led to the development of professionally produced journalistic products that are later disseminated by university media, for example, or to providing materials for the documentation of campaigns undertaken by Non-Governmental Organisations (Delponti-Macchione; Rodríguez-Wangüemert, 2019).

However, there is one variation of particular interest that reproduces professional routines but transcends university media. The project consists of producing journalistic products to be broadcast by professional media organisations, which in this case is on a platform of the Basque Public Radio and Television organisation (Cantalapiedra-González; Peña-Fernández; Pérez-Dasilva, 2011). The project was developed in journalistic writing courses at the Universidad del País Vasco (UPV-EHU) and is an example of collaboration between university and business beyond the mandatory curriculum. The objectives were to develop students' ability to produce multimedia content and to become familiar with a type of journalism in which communication is a two-way process that takes the form of citizen journalism fostered by technological development. Basque Radio and Television (EITB) made room for students' work on its citizen journalism platform. In fact, one of the outcomes of the project was the signing of a collaboration agreement between the university and the Basque broadcaster.

The authors measured the results by using a questionnaire given to the students, as well as by collecting data on the number of publications and comments they elicited. Apart from technical difficulties, one of the negative aspects included the fact that the publications were subject to being corrected twice (by the professors and by the media), which meant that the publication was delayed and lost its timeliness. On the positive side, the authors highlight the strong learning outcomes in terms of bringing professional practice and education closer together, thereby forging closer ties between universities and companies, the development of competence in facing real problems in the creation of multimedia news content, greater interest in providing quality content and taking responsibility for it, and the satisfaction that comes with the visibility of publication in the citizen journalism blog of a professional media outlet.

This type of service-learning would be similar to what Bueno-Doral and Hanninen (2012) have called the "real social project method". These authors have used it to propose that communication students design activities related to certain social initiatives (awareness-raising campaigns, etc.), and then carry them out, thereby improving the learning-by-doing outcomes by getting students to be

"emotionally involved with the teaching project" (Bueno-Doral; Hanninen, 2012, p. 163).

One of the projects launched is within the context of the Africa Exists Convention http://africaexiste.blogspot.com

This is an event organised entirely by second year Journalism students, which was created in the subject "Fundamentos de las Relaciones Públicas" (Fundamentals of Public Relations) with a dual purpose:

1) to make the African reality widely known and raise students' awareness of the complexity of the continent; and

2 ) to learn the main techniques of public relations in a practical way. 
This is an example of learning-by-doing, a live communication strategy where students work for four months in order to design and carry out a real event, and where the results reveal increased retention of knowledge and greater individual involvement of students in their own learning.

However, the work of Bueno-Doral and Hanninen (2012) aims to show that the learning-by-doing strategy alone does not allow students to achieve levels of excellence if they are not motivated and emotionally involved in the teaching project, and they must also be required to have the necessary framework of prior theoretical and technical knowledge to enable them to carry out professional work. In order to improve the educational training of Journalism students, the authors combined the experiential learning methodology with the real social project method, as well as some techniques of the collaborative learning model, and have obtained very positive results in student evaluations.

Lacalle-Zalduendo and Pujol-Ozonas (2019) describe an interesting case in this context of project-based learning. It involved 130 students ( 83 women and 47 men) from four different semester subjects (three in the fourth year of the degree and one in the third year), who taught 25 young people from the therapeutic-educational centre (10 women and 15 men) both to produce and interpret media content, while at the same time both groups exchanged experiences. The subjects of the service-learning programme are aimed at strengthening the skills of Journalism Degree students in digital journalistic production (Producción Periodística Multiplataforma - Multiplatform Journalistic Production), critical interpretation of media (Semiótica de la Comunicación - Semiotics of Communication), intercultural aspects (Comunicación Intercultural - Intercultural Communication), and education in communication. The four subjects are optional in the Universitat Autònoma de Barcelona (UAB) Journalism Degree and were chosen for their affinity with the objectives of this pedagogical model of service-learning.

Analysis of the perceptions of the $U A B$ students and the young people from the therapeutic-educational association regarding the SL project was carried out by means of questionnaires and focus groups. A total of $97.3 \%$ of the students rated the integration of this project into their Journalism studies very positively, and $53.3 \%$ considered that this experience had a positive impact on their studies. In general terms, the SL experience allowed them to test the skills acquired throughout the degree, as well as to conceptualise and structure the knowledge learnt in the different subjects addressed in the practical training.

Marta-Lazo and González-Aldea (2012) compiled the results obtained in a service-learning project carried out in the Bachelor's Degree in Journalism Programme at the Universidad de Zaragoza, in the context of three subjects: Empresa de Comunicación (the Communication Business), Géneros Informativos en Televisión (Television News Genres), and Producción de Informativos en Televisión (Television News Production). The service activity consisted of producing a television report showing the social activities of non-profit organisations. The students would thus become aware of the importance of the journalistic profession as a public service. By means of a self-assessment questionnaire on the service provided, the students evaluated the activity and concluded that the endeavour was useful on a personal and professional level for improving their civic values and helping them become aware of the social responsibility of the journalistic profession.

Along the same lines, another study was published by these same professors (González-Aldea; Marta-Lazo, 2015), who presented the results of a teaching innovation project that integrated service-Learning into the subject of "Información Periodística sobre Situaciones, Tendencias y Problemas Sociales" (Journalistic News Related to Situations, Trends and Social Problems) in the Journalism Degree at Universidad Carlos III de Madrid. The aim was to make the work of associations committed to social causes more visible and convey positive examples to society, while students developed skills in reporting on complex social issues. The method of analysis consisted of a student questionnaire. Regarding the results, it could be observed that experiential learning was fundamental in overcoming stereotypes and prejudices about certain issues and groups, and that good professional practices were promoted.

\subsection{Project-based learning (PBL)}

Active learning is intrinsic to project-based learning (PBL). PBL first appeared in Denmark during the 1970s, more specifically at the Roskilde University Centre (1972) and Aalborg University (1974) (De Graaff; Kolmos, 2007). In Spain, this methodology has been relatively successful. In recent decades, a significant number of initiatives have been carried out. In most cases, however, they have been limited to implementation in individual subjects without a broad impact on the curricula of degrees (García-Martín; Pérez-Martínez, 2018).

García-Martín and Pérez-Martínez (2018) clearly explain how this inductive methodology is considered to be student-centred, active learning, as the educational process places more responsibility on the student for his or her own learning, requiring them to make an effort to discuss and solve problems from the beginning of instruction. Moreover, these teaching methods are based on the idea of constructivism, or in other words, on students constructing their own version of reality and knowledge through their own experience rather than absorbing the reality and knowledge presented by the professor. 
Sánchez-Duarte and Fernández-Romero (2015) have reported the results of project-based learning in the subject entitled "Periodismo Multimedia" (Multimedia Journalism) in the Bachelor's Degree in Journalism Programme at Universidad Rey Juan Carlos. Students were asked to develop a project to create a digital media communication company in groups (between 6 and 8 people), in which the essential components of the subject were incorporated. The course was organised on the basis of lectures (two hours per week) in which the theoretical bases of the discipline were addressed, as well as a series of hands-on workshops (also lasting two hours per week) in which the practical components of the project were developed. In addition, several of the hands-on sessions were devoted to personal tutorials with the different groups of students in order to identify the shortcomings of the project and offer suggestions for improvement.

According to the results obtained by the students in this subject, it was clear that the elimination of rote learning meant taking on a challenge that increased student involvement and awakened their interest in seeking new tools, experimenting with new ways of learning, and developing their own innovative projects. At the same time, the broadening of competencies and skills involved in carrying out a project from conception to implementation and dissemination meant that students had to go well beyond their usual, everyday area of expertise and face responsibilities such as constant decision-making and taking on leadership roles.

In addition to the on-site degree, blended learning is also one of the characteristics of the degrees related to Journalism taught at Universidad Rey Juan Carlos. Gertrudix (2018), who is one of the professors, recently published in the "Banco de buenas prácticas docentes" (Archive of best teaching practice) the results of a teaching innovation proposal implemented in the subject entitled "Planificación y desarrollo de proyectos en la Red" (Planning and Development of Web-based projects), as part of the blended learning model of the Journalism degree. The proposal incorporates the following features: tutorial education by videoconferencing; use of the case method for critical analysis of the phenomenon of digital communication; the assignment of tasks in order to coordinate collaborative group work aimed at the development of an online journalistic project; and a review of the Keller Plan in order to carry out mentored training in web languages. In addition, the proposal integrates the complete development of the subject content, and in turn, these materials are offered openly in accordance with the model of open educational practices and OERs (open education resources).

The results of this study revealed improved group integration as well as the definition of specific tasks with clearer and more mutually agreed upon milestones and deadlines. This has also led to a stronger commitment by most of the students to achieve a professional finish to the product, because they see it as an opportunity to add a project to their portfolio as a future reference of the professional competence they have achieved in this field.

Herrero-Diz and Varona-Aramburu (2017) have published their successful experience that involved applying the collaborative, project-based learning model to the subject of "Periodismo digital" (Digital Journalism) in the Communication Degree at Universidad Loyola Andalucía. They took advantage of a local event that involved the possibility of having global repercussions and international implications in the future, with the additional aim of integrating international students belonging to the Erasmus programme. The event was the celebration of the 500 Year Anniversary of the First Circumnavigation of the World (2019-2022). As described by the authors, the Digital Journalism classes were organised as if they were a large digital newsroom. In addition to having computers in the classrooms equipped to carry out journalistic tasks, all mobile devices that allow for the creation of digital content were welcome, enabling both the tasks of the mobile journalist (a profile on the rise) and experimentation with new narratives that are becoming a trend in the professional world.

Evaluation of the impact of this teaching methodology on students was carried out by means of a questionnaire. The results show that collaborative, project-based learning was a useful and coherent strategy in the teaching of digital journalism due to the benefits that professors encountered, such as the following: the development of professional competencies; the improvement of skills and abilities related to the search for information, its selection and processing; the ability to create different formats; the use of different languages depending on the content distribution platform; and finally, web-based interaction with all types of users, in addition to other miscellaneous advantages. López-Meri (2016) combined cooperative learning and project-based learning with a creative methodology aimed at improving teamwork and collaborative learning, creating a climate of entrepreneurship in the classroom, and encouraging greater student involvement in their own learning. The teaching experience was put into practice in the subject entitled "Comunicación para la Igualdad" (Communication for Equality) in the Journalism Degree at Universitat Jaume I in Castellón, Spain.

By means of a questionnaire, the professor was able to observe student satisfaction with this innovative teaching approach. The students reacted enthusiastically to the innovations introduced both in the team-building phase and in the phase of generating and prioritising proposals. On the other hand, students sometimes respond badly to an excess of autonomy. Without periodic, measurable deadlines for turning in work, they often feel lost, postpone decision-making, and wait for others to take the first step. For this reason, the initial phases of activity were developed as usual and guided by the professor, but the pace of work and involvement of the professor decreased as the level of responsibility and freedom for self-management of the teams increased.

In contrast to traditional methods, innovative teaching initiatives in journalistic education place active student learning at the centre of the educational process 
Camacho (2016) presents the results of a project-based learning experience in the subject "Periodismo Especializado" (Specialised Journalism), which is part of the Bachelor's Degree in Journalism at the Universidad del País Vasco. The project consisted of launching a specialised magazine for which the students had to create a design and layout, and produce the content. The assessment of this experience is based on a survey of the students' opinion, the results of which reveal the following, among other issues:

- improvement in the level of student activity;

- reduced absenteeism;

- improved student learning;

- fostering the development of interpersonal skills and teamwork; and

- bringing the course activity closer to professional activity.

In another article, Paniagua-Rojano, Gómez-Aguilar and González-Cortés (2014) present a teaching innovation activity founded on project-based learning for the subject entitled "Creación y Gestión de Empresas Informativas" (Creating and Managing News Companies) in the Journalism Degree at the Universidad de Málaga. The aim was to create and develop a journalistic company that would be viable in today's society, and needed to include the following: the company's mission statement and vision, legal structure, context analysis, coverage, the company's competitors, dissemination and marketing plan; defining the sections, content and services; and finally, drawing up a budget and a financial viability plan.

To evaluate the results of applying the teaching methodology, direct observation of the students' daily work both in class and in tutorials was proposed, as well as an analysis of the academic results obtained by the students. Moreover, an online survey of the students' perception of the subject was carried out. The results showed that $91 \%$ of the students surveyed assured that after having taken the subject, they would consider setting up their own company. Before taking the subject, this percentage was only $39 \%$. However, a series of educational deficiencies were observed among the students in relation to the subject, some examples of which included content related to economics, business, budgeting, and the analysis of context and competition as preliminary steps in launching an entrepreneurial project. This implies the need to improve coordination with professors of subjects related to specialised journalism, digital journalism, and the new media, which implies a new challenge for the next academic year.

Larrondo et al. (2020) propose the Internationalisation at Home strategy (IaH) as a pedagogical innovation initiative contextualised within project-based learning for the teaching of cyber journalism. PBL is the methodology on which the majority of cyber journalism subjects in Latin America are based, which involve the development of in-depth journalistic projects of a multimedia and transmedia nature (Fernandes-Teixeira; Larrondo, 2019). This is a joint project involving several Ibero-American universities, although in the case of Spain, the specific subject would be "Redacción Ciberperiodística" (Cyber journalistic Writing) at the Universidad del País Vasco. The project involved a total of five international work teams, each comprising two Portuguese students, two Brazilian, and one Basque student. Evaluation of the project was carried out through meetings and discussions with the students themselves, concluding that in addition to the usual or typical difficulties with teamwork, there were other constraints specific to the project, such as the type of virtual asynchronous communication among the participants and the level of knowledge of the common language used, which was English.

\subsection{Content curation}

The term content curator refers to those practices related to the location, selection and organisation of materials from different sources and formats in order to build a story (Martínez-Nicolás, 2016).

Codina, Guallar and Lopezosa (2020, p. 4) propose a definition of content curation for the professional activity of journalists, and state that

"content curation is the process of selecting and compiling relevant information for a given topic and audience with the intention of adding value to it, and disseminating it as well. This often involves the prior need to search for information, as well as to design monitoring processes for the main sources of information".

This being the case, it seems evident that this coincides with the very essence of journalistic practice: composing stories in the form of news, features, reports, etc., based on the data collected by the journalist. In this context of content curator, Guallar and Leiva (2013) talk about the 4S model, according to which content curation in journalism is a process with four sequential phases: Searching for information, Selecting it, making Sense of it, and Sharing it. A curator is basically someone who holds in his or her hands a large amount of news material and converts chaos into order, or in the new jargon, converts "noise into signals" (Guerrini, 2013). This author takes an interesting approach to the term by exposing in this same publication two examples of how this "curation" of information should be performed: one is based on the riots that took place in the summer of 2010 in London following the murder of a black man by police, and the other is based on the "Occupy Wall Street" movement.

With the rise of social media platforms and the avalanche of fragmented content from users, content curation now plays a central role in how news is created by newsrooms and delivered to an audience. Without relinquishing their traditional skills, journalists are increasingly becoming information "managers". 
However, the term has arisen in strict association with the digital environment, and especially with the emergence of web 2.0 and the rise of the so-called social media (Twitter, Facebook, YouTube, Instagram, and Flickr), where users also assume the status of producers and disseminators of content accessible on the internet. In these new conditions, the task of locating and selecting materials and, above all, organising them into a single document suitable for digital publication does not appear to be an easy task, hence the development of tools that enable such management or curatorship of the content circulating on these social media channels.

Innovative teaching experiences along these lines have introduced students to the new informative narratives that utilise digital tools in order to allow them to search on social networks for documents in any type of format (textual, icon-related, audio, graphic, etc.) on a topic specified by the user, which also offers a kind of template for constructing a story that can be published. Some experiences in the teaching of journalism using Storify have been recorded during the time it was available, up until May of 2018 (Herrero-Curiel; Limón-Serrano, 2014). Current interest is focused on the possibility of resuming such teaching experiences using similar devices to build news stories (Wakelet, for example) (Godoy, 2018). Along the same lines, there is also the so-called Live Blogging concept (Thurman; Walters, 2012), which is being used increasingly by the media. It combines conventional reporting with content curation, where journalists select and prioritise information from secondary sources and present it to the audience nearly in real time, often incorporating their comments.

While these tools are already being used professionally in the field of journalism, their pedagogical use fulfils at least three types of competencies needed by students of this degree:

- the handling of potentially newsworthy sources hosted on the web 2.0;

- working in an exclusively digital environment, in line with what is already demanded by companies in the sector; and

- the production of journalistic products of a multimedia nature by integrating texts, photographs, videos, graphics, sound resources, etc.

\subsection{Collaborative digital tools}

Dafonte-Gómez, García-Crespo y Ramahí-García (2018) consider that technology is not only used for traditionally "technological" tasks, but in a transversal way as well. In fact, the different projects presented herein reflect a form of learning that is supported by technology, but not necessarily focused on it. The use of wikis, sharing documents through Google Drive, carrying out a survey by using the web, and using Facebook for academic purposes or teamwork, are just some of the options that can be pointed out in this section on collaborative digital tools.

The work published by Pérez-Serrano, Fernández-Sande and Rodríguez-Pallarés (2020) is one of the most recent, and is based on their experience with the subject entitled "Teoría de la Empresa Informativa" (Theory of the News Company). The professors designed a work plan that was systematically divided into actors or students, tools, and a Gantt chart or timeline. Regarding the part that concerns us here, the digital tools used were the following:

- Simul@, from the Spanish Ministry of Industry, Trade and Tourism;

- Socrative, a free application that allows assessments by means of a quiz (questionnaire), Space Race (a time-based questionnaire), Exit Ticket (a questionnaire with the ranking of results); and

- Google Forms to discover the students' impression of the experience.

At the end of the course, $95 \%$ of the students rated the experience with an overall score of more than 9 out of 10 . The positive assessment and standardisation of the results obtained reaffirm the enhanced benefits of the subject and an increase in student understanding of the key content, according to the professors.

In a study by Teruel-Rodríguez (2013), this researcher offers an experience of student motivation in Journalism Degree subjects, the results of which show improvement not only in students' marks, but also in the way that constructive, enduring learning has been achieved by implementing this teaching innovation project and the tools offered by the social web.

The work of Bernadas-Suñé and Lázaro-Pernias (2011) is yet another example of the use of these digital tools in the context of journalism degrees at the Universitat Autònoma de Barcelona. The team of professors oriented their work toward re-thinking how to transmit traditional content related to audio-visual languages through greater use of ICT, with the aim of improving and optimising the theoretical-practical relationship of the teaching-learning process.

In another case, in order to address a transversal competence such as the need for future reporters to be well acquainted with current affairs, professors at the Universidad del País Vasco designed a project (Peña et al., 2011) with the aim of developing student competence in being well informed, for which an innovation project was designed that provided students with weekly online current affairs tests in order to self-evaluate their knowledge of current events, and deepen it as well. They took the tests on-site in the classroom once a month, and a time slot was reserved for the final test in the subject.

The competence to be developed was not only knowledge of current affairs but also the habit of staying informed, hence the importance of autonomous learning:

"The project thus defined lies within the framework of the cooperative, dynamic, student-centred teaching-learning model (IKD, integrated knowledge dynamics)" (Peña et al., 2011, p. 67). 
The tool developed used a platform to generate the current affairs questionnaires that also allowed the information to be contextualised and the students to delve deeper into the news. Again, collaboration with EITB, the Basque public broadcaster, made the project possible by providing the context of the news being reviewed.

In order to evaluate the project, an initial survey was designed to see which media the students were using to stay informed and the knowledge they had of current affairs. A questionnaire was designed to test the results of the project at the end of the four-month period. However, the publication only includes the initial results, which suggest a successful outcome, given that the percentage of students who took the test and completed it was over $70 \%$. The project was carried out in both languages (Basque and Spanish), and involved approximately half of the students in the first year of the degrees in Communication.

In the subject entitled Técnicas de redacción de textos (Text Writing Techniques), Bueno-Doral and Hanninen (2012) have recognised the use of these tools with the creation of the subject on Facebook, and on a blog as well, which are two fundamental initiatives in fostering interactivity between all the components of the project. Moreover, the project was fully student-driven. Advertising agencies, educational centres, and professionals related to the subject had the opportunity to become "friends" and "fans" of the students" work, contributing to its dissemination.

A group of professors from the Faculty of Communication Sciences at the University of Málaga launched an educational innovation project that consisted of the creation of video tutorials and the association of QR codes on the different equipment in the audio-visual laboratories (Monedero; Castro; Luengo, 2017). These are curricular videos that explain and complement the content taught in class. The media chosen for the training videos is YouTube at the following link: https://www.youtube.com/channel/UCyODLeMIUOonn/SdZ7FpOWw

A channel was created called, "Proyecto Innovación Educativa (PIE) Ciencias de la Comunicación UMA" (Teaching Innovation Project, Communication Sciences UMA), in which the training materials were made available to the public independently or grouped in playlists that enabled user access to related content. After an initial needs analysis survey, the authors of this innovative teaching technique concluded that the use of video tutorials as a learning tool is perceived as necessary by a high percentage of students of the three degrees in Communication Sciences. In fact, according to the authors, this technique helped improve assimilation of the learning objectives content in the case of students who participated in its development, and at the same time it was easier for student users to remember the content.

\subsection{Edublogs}

Blogs are sites hosted on the Internet, usually specialised in a particular subject, with content in any format that is regularly updated by the creator. Blogs also allow for linking or forwarding to other pages and interacting with readers if it is open to their participation. Within these three characteristics (thematic specialisation, linking with related sites, and openness to interaction) lies the potential of the blog to build a kind of "community of interest" around the issues discussed therein. An edublog is nothing more than a weblog with the main objective being to support a teaching-learning process in an educational context (Lara, 2005).

In the field of journalism, blogs created by professionals themselves were seen from the outset as a way of removing the production and dissemination of publicly relevant information from the monopoly exercised by journalistic companies de facto (Blood, 2003; Cebrián-Herreros; Flores-Vivar, 2007). Maintaining a blog thereby represented the possibility of creating an autonomous profile detached from any editorial policy other than the one that was personally chosen by the journalist. In its application as a learning tool in teaching journalism at universities, the use of blogs for educational purposes allows for the re-creation of these dynamics of the professional world, and also allows students to start building a curriculum vitae that already has a professional appearance with

"a competitive, effective and forward-looking online presence" (Pou et al., 2013, p. 551).

The edublog thus functions as a public showcase for students' work which, as a published product, is also subject to the scrutiny and interaction of an audience initially composed of the rest of the students and the professors. This makes it a useful tool for delving into the application of collaborative teaching-learning methods in conditions that are similar to how they work in the professional world.

López-Vidales and González-Aldea (2014) describe the experience carried out with 199 students of the Journalism Degree at the Universidad de Valladolid, which analysed the extent to which blogs enhanced both individual and group skills and competencies. The aim was to determine the advantages and difficulties of collaborative learning in the virtual environment of the blogosphere. To this end, new hybrid formats, audioblogs, and TV blogs were used to design the practical training for the subjects "Radio Informativa" (Radio News) and "Televisión Informativa" (Television News). The main objective of the project was to determine to what extent the new digital tools based on the creation of weblogs were useful for teamwork in the subjects of Radio News and Television News, both of which are compulsory courses [6 ECTS (European credit transfer and accumulation system)], which are part of the Journalism Degree at the university.

Proposals for innovation in journalistic education revolve around three objectives: competency-based learning, student-centred teaching, and active learning 
These authors concluded that these weblogs allowed students not only to learn how to develop an idea for an audio-visual programme in a virtual environment, but also to understand the need to work in a team in order to carry out a media project. Moreover, they became familiar with the usual techniques of writing, correcting, editing, and organising messages and news, and they learned to appreciate the opinion of the other members of their own group and the rest of the class as well. They also realised the importance of individual work in carrying out a collaborative project, increasing their degree of involvement and responsibility in the tasks, and working on their capacity for self-criticism in the development of a real professional project.

Pou-Américo, Álvarez-Villa and Mercado-Sáez (2013) present three coordinated teaching experiences in the creation and use of edublogs in Journalism studies from the perspective of competency-based education. For these authors, blogs in the journalistic environment are seen as platforms on which to develop personalised, heterogeneous content with a strong impact on social networks, together with reduced production and maintenance costs. This professional reality makes it necessary for future journalists to incorporate the skills to manage a blog, among others as well. Working on this allows Journalism students to achieve continuous training and even provide their professional profile with an online presence that is competitive, effective, and future-oriented.

For this teaching innovation experience, subjects from different courses and a variety of content were taken into account: Teoría y técnica radiofónica (Radio Theory and Technique) in the $2^{\text {nd }}$ year, Periodismo de opinión (Opinion Journalism) in the $3^{\text {rd }}$ year, and Periodismo Cultural (Cultural Journalism) in the $5^{\text {th }}$ year. In all three cases, students were asked to create a blog related to the subject matter. To do so, they had free platforms available on the Internet. On the platforms, they were required to register and create a publicly accessible blog to which they had to add content periodically. Classmates, professors, and the general public could comment on their posts. Once the semester was over, the blog was part of the evaluation.

Regarding their assessment of the activity, Pou-Américo, Álvarez-Villa and Mercado-Sáez (2013) believe it is generally positive because it helps students to apply knowledge and develop skills that they will need to know in their future working environment, in addition to helping them build an online presence and enhance their entrepreneurial character. However, these authors recognise that improvements need to be made with regard to collaborative learning and the debates that can arise in relation to the published topics.

\subsection{Immersive virtual environments}

Immersive environments, or 3D virtual worlds, are graphic depictions of a three-dimensional environment generated by a computer programme (Second Life, OpenSim, etc.), simulating scenarios with a realistic appearance that can be occupied or "inhabited" by a figure, generally anthropomorphic, associated with the user (the so-called avatar), and where this avatar can perform actions (move around, handle objects, build new components, etc.) and interact with the avatars of other users. The attraction of these virtual environments lies in the realism of the graphic re-creations of scenarios and figures, in the sensation of co-presence of the participants in the same time and space, and in the possibility of carrying out realistic interaction, visually simulated on the screen, yet real and immediate with the use of other means of communication, such as voice or text (Rodríguez-García; Baños-González; Rajas-Fernández, 2016). Such features thereby make these virtual worlds a pedagogical tool that is especially suitable for overcoming some of the disadvantages of non-classroom teaching.

The design of teaching activities in these immersive learning environments requires, among other aspects, the creation (or management if already available) of the graphic spaces or scenarios where the participants will interact, and preparation of the activities to be developed therein. There is no documented evidence of its use in journalistic teaching, yet there are examples of its use in related degrees. An example of such use can be found in the online teaching of Advertising and Public Relations, where these virtual worlds have been used to interact through avatars in graphic scenarios that represent real work spaces (rooms of an advertising agency, classrooms, professors' offices, etc.), in which the appropriate training activities are carried out for each of these spaces: brainstorming sessions, discussions of advertising campaigns, presentation of work, personalised tutorials, etc. (Rodríguez-García; Baños-González; Rajas-Fernández, 2016). It would not be difficult to transfer this experience to the subject of Journalism, an example of which could be simulating and carrying out actions virtually in newsrooms or editorial board meetings. In any case, what is most striking is the potential of these tools to generate environments that foster interaction between students and professors in shared spaces simultaneously, thereby compensating (at least in part) for the shortcomings of remote teaching.

\section{Conclusions}

A global technological transformation is taking place in Europe within a context of change, and is affecting educational models as well. Journalism studies are no exception, and educational change is coinciding with major technological transformations in the sector. Technological progress is an ally of educational innovation. The former undoubtedly implies innovation, not always educational innovation.

The three pillars, or objectives, that seem to have been pursued by teaching innovation proposals in Journalism studies developed to date revolve around competency-based learning, student-centred teaching, and active learning. One 
way or another, in all of them the professor is increasingly using technology to try to motivate the student and make him or her participate in an involved, active way in his or her own educational training. However, it must not be forgotten that technology is an instrument, or a means of achieving better-trained graduates for the labour market.

Although the majority of the projects reviewed herein include instruments for assessing the success of the innovation initiatives in question, there is no reference to the relationship that one would expect between assessment of the subject and assessment of the innovation project. Determining what influence the incorporation of innovation has had on learning necessarily involves seeing to what extent it has improved learning outcomes, as evidenced by graded tests in the subjects. Therefore, an improvement in marks obtained by students in the subject exams where innovation projects have been implemented might confirm the success of the project beyond the students' perception of the experience itself.

Along the same lines, it will be necessary to ensure that these teaching innovation projects do not become individual initiatives implemented on an experimental basis at a specific academic moment in time. In fact, there are very few examples of innovative projects having been implemented over the course of several academic years. This situation undermines the effectiveness of innovation, because its lack of sustainability over time, among other reasons, prevents stability in the variables that affect learning outcomes. Without this stability, it is difficult to carry out an analysis of results comparing different academic years, depending on whether innovation has been incorporated or not. If this is not the case, we only obtain still photos of isolated moments and experiences, and not a continuous image of the process that would allow us to speak not only of innovation, but of real progress in learning.

The challenge is therefore two-fold. On the one hand, it is necessary to define instruments that evaluate the knowledge and skills acquired and identify the dimensions that make it possible to evaluate the quality of e-learning programmes. On the other hand, the second challenge is to improve evaluations and give continuity to proposals for teaching innovation that come from the centres themselves.

Finally, it will be necessary to delve deeper into this line of investigation with the aim of complementing the research conducted in this article with other review studies that will allow for the observation of activities being carried out in centres in other countries that compose the European Higher Education Area.

\section{References}

Álvarez-Nobell, Alejandro; Vadillo-Bengoa, Nerea (2013). “Innovación en la enseñanza de posgrado en comunicación: el aprendizaje-servicio como estrategia pedagógica". Historia y comunicación social, v. 18, n. especial, pp. $263-277$. https://doi.org/10.5209/rev_HICS.2013.v18.44326

Bernadas-Suñé, Dolors; Lázaro-Pernias, Patricia (2011). “El lenguaje audiovisual en los grados de comunicación: nueva metodología docente". Vivat academia, n. 117, extra, pp. 353-367.

https://doi.org/10.15178/va.2011.117E.353-367

Blanco-Alfonso, Ignacio; García-Galera, Carmen; Tejedor, Santiago (2019). "El impacto de las fake news en la investigación en Ciencias Sociales. Revisión bibliográfica sistematizada". Historia y comunicación social, v. 24, n. 2, pp. 449-469. https://doi.org/10.5209/hics.66290

Blood, Rebecca (2003). "Weblogs and journalism: Do they connect?". Nieman reports, v. 57, n. 3, pp. 61-63. https://niemanreports.org/wp-content/uploads/2014/04/03fall.pdf

Bradshaw, Paul (2013). “Journalism *is* curation: tips on curation tools and techniques". Online journalism blog. https://onlinejournalismblog.com/2013/09/30/curation-tools-tips-advice-journalism

Bueno-Doral, Tamara; Hanninen, Liisa-Irene (2012). “Innovación docente con jóvenes interactivos: proyectos sociales reales y estrategias digitales para enseñar comunicación”. Estudios sobre el mensaje periodístico, v. 18, n. especial, pp. 161-170.

https://doi.org/10.5209/rev_ESMP.2012.v18.40892

Cáceres, César; Esteban, Natalia; Gálvez, María-del-Carmen; Rivas, Begoña (2019). Competencia digital docente: una perspectiva de futuro en la Educación Superior. Madrid: Dykinson. ISBN: 9788413244303

Camacho, Idoia (2016). "Una experiencia de aprendizaje basado en proyectos en el grado de periodismo". En: IX Congreso iberoamericano de docencia universitaria, pp. 391-395.

https://www.aidu-asociacion.org/una-experiencia-de-aprendizaje-basado-en-proyectos-en-el-grado-de-periodismo 
Cantalapiedra-González, María-José; Peña-Fernández, Simón; Pérez-Dasilva, Jesús-Ángel (2011). “Uso de la web 2.0 en el aprendizaje de la redacción periodística: una experiencia de periodismo ciudadano". Comunicação \& inovação, v. 12, n. 23, pp. 3-10.

https://doi.org/10.13037/ci.vol12n23.1376

Cebrián-Herreros, Mariano; Flores-Vivar, Jesús-Miguel (coords.) (2007). Blogs y periodismo en la Red. Madrid: Fragua. ISBN: 9788470742071

Codina, Lluís (2018). "Revisiones sistematizadas para trabajos académicos 1: Conceptos, fases y bibliografía". Blog Lluís Codina, 11 abril.

https://www.lluiscodina.com/revisiones-sistematizadas-fundamentos

Codina, Luis; Guallar, Javier; Lopezosa, Carlos (2020). Curación de contenidos para periodistas: conceptos, esquema de trabajo y fuentes abiertas. Barcelona: Grupo DigiDoc.

https://repositori.upf.edu/handle/10230/43458

Dafonte-Gómez, Alberto; García-Crespo, Oswaldo; Ramahí-García, Diana (2018). “Flipped learning y competencia digital: Diseño tecnopedagógico y percepción del alumnado universitario". Index.comunicación, v. 8, n. 2, pp. $275-294$. https://journals.sfu.ca/indexcomunicacion/index.php/indexcomunicacion/article/view/373/398

De-Graaff, Erike; Kolmos, Anette (2007). "History of problem-based and project-based learning”. En: De-Graaff, Erike; Kolmos, Annete (eds.). Management of change: implementation of problem-based and project-based learning in engineering. Rotterdam: Brill Sense, pp. 1-8. ISBN: 9789087900922

https://doi.org/10.1163/9789087900922

De-la-Iglesia-Villasol, María-Covadonga (2019). “Caja de herramientas 4.0 para el docente en la era de la evaluación por competencias". Innovación educativa, v. 18, n. 80, pp. 93-112.

http://www.scielo.org.mx/scielo.php?script=sci_arttext\&pid=S1665-26732019000200093

Delponti-Macchione, Patricia-Adriana; Rodríguez-Wangüemert, Carmen (2019). "Innovación en el aprendizaje de servicio en los estudios de comunicación. El valor de la imagen en el periodismo". En: Vega-Navarro, Ana; Stendardi, David (coords.). De la innovación imaginada a los procesos de cambio. La Laguna: Universidad de La Laguna, pp. 167-176. ISBN: 9788415939627

Educaweb (2019). "Innovación educativa: 5 tendencias que puedes aplicar en el aula”. Educaweb, 19 septiembre. https://www.educaweb.com/noticia/2017/09/19/innovacion-educativa-5-tendencias-puedes-aplicar-aula-15112

Espinosa, Javier K.; Jiménez, J.; Olabe, Mikel; Basogain, Xavier (2006). Innovación docente para el desarrollo de competencias en el EEES.

http://campus.usal.es/ ofeees/ARTICULOS/p216.pdf

Fernandes-Teixeira, Juliana; Larrondo, Ainara (2019). “O ensino universitário do ciberjornalismo no Brasil e na Espanha: respostas formativas e desafios futuros no contexto convergente e social”. Observatorio (OBS*), v. 13, n. 4, pp. 89-106. http://obs.obercom.pt/index.php/obs/article/view/1402

Gálvez-de-la-Cuesta, María-del-Carmen; Esteban-Sánchez, Natalia; Rivas-Rebaque, Begoña (2019). “El Banco de Buenas Prácticas Docentes de la Universidad Rey Juan Carlos". En: Cáceres-Taladriz, César; Esteban, Natalia; Gálvez-de-laCuesta, María-del-Carmen; Rivas-Rebaque, Begoña (eds.). Competencia digital docente: una perspectiva de futuro en la Educación Superior. Madrid, Dykinson, pp. 1-50. ISBN: 9788413244303

García-Martín, Javier; Pérez-Martínez, Jorge-Enrique (2018). “Aprendizaje basado en proyectos: método para el diseño de actividades". Tecnología, ciencia y educación, n. 10, pp. 37-63.

https://www.tecnologia-ciencia-educacion.com/index.php/TCE/article/view/194

García-Retamero-Redondo, Javier (2010). “De profesor tradicional a profesor innovador”. Temas para la educación, n. 11, pp. 1-7. https://www.feandalucia.ccoo.es/docu/p5sd7620.pdf

Gertrudix, Manuel (2018). “Desarrollo de competencias profesionales en Periodismo semipresencial mediante REAs, contrato de tareas y Plan Keller". En: Banco de buenas prácticas docentes URJC.

https://bit.ly/2RQhALs

Godoy-Rodríguez, Carlos (2018). "Wakelet: nueva herramienta para curar contenidos educativos digitales". Docente curador, 10 junio.

https://docentecurador.com/wakelet-herramienta-para-curar-contenidos-educativos-digitales

González-Aldea, Patricia; Marta-Lazo, Carmen (2015). “La metodología del aprendizaje-servicio como herramienta en la formación de los periodistas". Opción, v. 31, n. 3, pp. 564-581.

https://www.redalyc.org/comocitar.oa?id=31045567029 
Gonzálvez-Vallés, Juan-Enrique (2014). Nuevas tendencias en innovación educativa superior. Madrid: Editorial ACCI. ISBN: 9788415705147

Guallar, Javier; Leiva-Aguilera, Javier (2013). El content curator. Guía básica para el nuevo profesional de internet. Barcelona: UOC. ISBN: 9788490640180

Guerrini, Federico (2013). Newsroom curators \& independent storytellers: content curation as a new form of journalism. Oxford: Reuters Institute for the Study of Journalism.

https://reutersinstitute.politics.ox.ac.uk/our-research/newsroom-curators-and-independent-storytellers-contentcuration-new-form-journalism

Guirao-Goris, Silamani J. Adolf (2015). “Utilidad y tipos de revisión de literatura”. Ene. Revista de enfermería, v. 9, n. 2. https://doi.org/10.4321/S1988-348X2015000200002

Herrero-Curiel, Eva; Limón-Serrano, Nieves (2014). “Multimedia content production inside the classroom. A teaching proposal for journalism and audiovisual communication students". Higher learning research communications, v. 4, n. 1, pp. 122-137.

https://doi.org/10.18870/h/rc.v4i1.201

Herrero-Diz, Paula; Varona-Aramburu, David (2017). "La primera vuelta al mundo multimedia: enseñanza de periodismo digital a través del aprendizaje basado en proyectos colaborativos". Textual \& visual media, n. 10, pp. 205-218.

https://textualvisualmedia.com/index.php/txtvmedia/article/view/47

Huang, Edgar; Davison, Karen; Shreve, Sthephanie; Davis, Twila; Bettendorf, Elisabeth; Nair, Anita (2006). "Bridging newsrooms and classrooms: Preparing the next generation of journalists for converged media". Journalism \& communication monographs, v. 8, n. 3, pp. 221-262.

https://doi.org/10.1177/152263790600800302

Johnson, David W.; Johnson, Roger T.; Holubec, Edythe J. (1999). El aprendizaje cooperativo en el aula. Buenos Aires: Paidós. ISBN: $950122144 \mathrm{X}$

https://www.ucm.es/data/cont/docs/1626-2019-03-15-JOHNSON\%20El\%20aprendizaje\%20cooperativo\%20en\%20 el\%20aula.pdf

Lacalle-Zalduendo, Charo; Pujol-Ozonas, Cristina (2019). “Mentoría e integración social en la universidad: el aprendizaje-servicio en un proyecto del grado de periodismo". Educación XX1, v. 22, n. 2, pp. 289-308.

http://revistas.uned.es/index.php/educacionXX1/article/view/22694

Lara, María; García-Castillo, Noelia; Bueno-Doral, Tamara (2018). "La innovación docente en los estudios de Comunicación: análisis documental de los proyectos financiados por las universidades públicas madrileñas”. CIC. Cuadernos de información y comunicación, v. 23, pp. 143-156.

https://doi.org/10.5209/CIYC.60911

Lara, Tíscar (2005). "Blogs para educar. Usos de los blogs en una pedagogía constructivista”. Telos, n. 65, pp. 86-93. https://telos.fundaciontelefonica.com/archivo/numero065/usos-de-los-blogs-en-una-pedagogia-constructivista

Larrondo, Ainara; Canavilhas, João; Fernandes-Teixeira, Juliana; Martins, Gerson-Luiz; Meso, Koldobika; Pérez-Dasilva, Jesús; Peña-Fernández, Simón; Zamith, Fernando (2020). “Educational innovation for the internationalization and convergence of university teaching of online journalism in Ibero-America". Anàlisi, n. 62, pp. 35-56.

https://doi.org/10.5565/rev/analisi.3264

Lee, Alice Y. L. (2013). "Literacy and competencies required to participate in knowledge societies". En: Lee, Alice Y. L.; Lau, Jesús; Carbo, Toni; Gendina, Natalia. Conceptual relationship of information literacy and media literacy in knowledge societies. Paris: Unesco.

http://www.unesco.org/new/fileadmin/MULTIMEDIA/HQ/CI/CI/pdf/wsis/WSIS_10_Event/Literacy_recommendations_-Prof_Lee.pdf

Llorens, Carles; Bonet, Montse (2016). “Innovación docente en los estudios de comunicación en España”. En: Gómez-Mompart, Josep-Lluís; Herrero-Subías, Mónica (coords.). Jornadas de formación y empleo en Comunicación. Barcelona: Atic, pp. 97-108.

http://titulaciones-atic.com/wp-content/uploads/2016/05/Jornadas-Formacio\%CC\%81n-y-Empleo-ATIC.pdf

López-García, Xosé; Rodríguez-Vázquez, Ana-Isabel; Pereira-Fariña, Xosé (2017). “Competencias tecnológicas y nuevos perfiles profesionales: desafíos del periodismo actual". Comunicar, n. 53, pp. 81-90.

https://doi.org/10.3916/C53-2017-08

López-Hidalgo, Antonio (2016). "El periodismo que contará el futuro". Chasqui. Revista latinoamericana de comunicación, n. 131, pp. 239-256.

https://revistachasqui.org/index.php/chasqui/article/view/2733/2746 
López-Meri, Amparo (2016). “Cooperación, creatividad y emprendimiento para el desarrollo de competencias. Una experiencia docente en Periodismo". En: Congreso nacional de innovación educativa y de docencia en red. IN-RED, 2016. https://riunet.upv.es/bitstream/handle/10251/94572/4337-10516-1-PB.pdf

López-Vidales, Nereida; González-Aldea, Patricia (2014). “Audioblogs y Tvblogs, herramientas para el aprendizaje colaborativo en Periodismo". Comunicar, n. 42, pp. 45-53.

https://doi.org/10.3916/C42-2014-04

Manterola, Carlos; Astudillo, Paula; Arias, Esteban; Claros, Nataniel (2013). "Revisiones sistemáticas de la literatura. Qué se debe saber acerca de ellas". Cirugía española, v. 91, n. 3, pp. 149-155.

https://doi.org/10.1016/j.ciresp.2011.07.009

Marta-Lazo, Carmen; González-Aldea, Patricia (2012). “El aprendizaje-servicio, una herramienta para el desarrollo profesional de la responsabilidad social del periodista". Estudios sobre el mensaje periodístico, v. 18, n. especial, pp. 577588.

https://doi.org/10.5209/rev_ESMP.2012.v18.40937

Martínez-Nicolás, Manuel (2016). “Innovación docente en el grado de periodismo de la Universidad Rey Juan Carlos en su modalidad semipresencial”. En: Gertrudix, Manuel; Esteban, Natalia; Hortal-Muñoz, José-Eloy; Gálvez-de-la-Cuesta, Carmen (eds.). La innovación docente con TIC como instrumento de innovación. Madrid: Dykinson, pp. 49-64. ISBN: 978 8490859742

Mauri, Teresa; Coll, César; Onrubia, Javier (2007). "La evaluación de la calidad de los procesos de innovación docente universitaria. Una perspectiva constructivista". Red U. Revista de docencia universitaria, n. 1. http://red-u.net/redu/files/journals/1/articles/47/public/47-36-2-PB.pdf

Monedero-Morales, Carmen-del-Rocío; Castro-Higueras, Antonio; Luengo-Benedicto, Juan-Tomás (2017) “Videotutoriales y códigos QR: recursos TIC en laboratorios de Ciencias de la Comunicación". Innoeduca. Innoeduca. International journal of technology and educational innovation, v. 3, n. 2, pp. 137-145.

https://doi.org/10.24310/innoeduca.2017.v3i2.2046

Murcia-Verdú, Francisco-José; Ufarte-Ruiz, María-José (2019). “Mapa de riesgos del periodismo hi-tech". Hipertext.net, n. 18, pp. 47-55.

https://doi.org/10.31009/hipertext.net.2019.i18.05

Newman, Nic (2020). Journalism, media and technology trends and predictions 2020. Oxford: Reuters Institute for the Study of Journalism.

https://bit.ly/3yaZ4yf

Paniagua-Rojano, Francisco-Javier; Gómez-Aguilar, Marisol; González-Cortés, María-Eugenia (2014). "Incentivar el emprendimiento periodístico desde la universidad". Revista latina de comunicación social, n. 69, pp. 548-570.

https://doi.org/10.4185/RLCS-2014-1024

Pavlik, John V. (2001). Journalism and new media. New York: Columbia University Press. ISBN: 9780231114837

Peinado-Miguel, Fernando; Fernández-Sande, Manuel; Rodríguez-Barba, Dolores; Ortiz-Sobrino, Miguel-Ángel (2013). "Aprendizaje e innovación: una propuesta metodológica desde la empresa informativa". Revista latina de comunicación social, n. 68, pp. 119-143.

http://doi.org/10.4185/RLCS-2013-971

Peña-Fernández, Simón; Lazkano-Arrillaga, Iñaki; Cantalapiedra, María-José; Iturregui-Mardaras, Leire; Agirre, Antxoka (2011). "Herramientas autoformativas en el área de Comunicación: Géneros informativos y los test de actualidad online”. En: Meso, Koldobika; Pérez-Dasilva, Jesús A.; Mendiguren, Terese (eds.). Primeras Jornadas de innovación educativa y nuevas metodologías docentes. Leioa: Servicio Editorial de la Universidad del País Vasco, pp. 62-75.

https://bit.ly/2QegR6m

Pérez-Seijo, Sara; Gutiérrez-Caneda, Beatriz; López-García, Xosé (2020). “Periodismo digital y alta tecnología: de la consolidación a los desafíos". Index.comunicación, v. 10, n. 3, pp. 129-152.

https://doi.org/10.33732/ixc/10/03Period

Pérez-Serrano, María-José; Fernández-Sande, Manuel; Rodríguez-Pallarés, Miriam (2020). “Entornos de aprendizaje digitales en el área de Empresa Informativa. Gaming e incidencia en actividades y evaluación”. Anàlisi, n. 62, pp. 111-130. https://doi.org/10.5565/rev/analisi.3288

Pou-Américo, María-José; Álvarez-Villa, Àngels; Mercado-Sáez, María-Teresa (2013). “Edublogs e innovación educativa en la enseñanza del periodismo". Historia y comunicación social, v. 18, n. especial, pp. 549-560.

https://doi.org/10.5209/rev_HICS.2013.v18.44348 
Ramírez-Ramírez, Leticia-Nayeli; Ramírez-Montoya, María-Soledad (2018). “El papel de las estrategias innovadoras en educación superior: retos en las sociedades del conocimiento". Revista de pedagogía, v. 39, n. 104, pp. 147-170. http://saber.ucv.ve/ojs/index.php/rev_ped/article/view/15707

Rodríguez-García, Teresa C.; Baños-González, Miguel; Rajas-Fernández, Mario (2016). “Docencia en el campo expandido: estudio de caso sobre aprendizajes en red”. Opción. Revista de ciencias humanas y sociales, v. 32, n. 8, pp. 597-618. https://produccioncientificaluz.org/index.php/opcion/article/view/21554/21362

Rodríguez-Pallarés, Miriam; Segado-Boj, Francisco (2020). “Competencias y habilidades periodísticas en el siglo XXI. Percepción de los estudiantes de periodismo en España”. adComunica, n. 20, pp. 67-94.

https://doi.org/10.6035/2174-0992.2020.20.4

Salaverría, Ramón (2015). “Periodismo en 2014: balance y tendencias. Cuadernos de periodistas, n. 29, pp. 9-22. http://www.cuadernosdeperiodistas.com/media/2015/01/09-22-SALAVERRIA.pdf

Salaverría, Ramón (2019). "PDigital journalism: 25 years of research. Review article”. El profesional de la información, v. 28, n. 1.

https://doi.org/10.3145/epi.2019.ene.01

Sánchez-Duarte, José-Manuel; Fernández-Romero, Diana (2015). “Pensar con la acción. Aprendizaje por proyecto en la enseñanza del periodismo digital”. Serbiluz, v. 31, n. 5, pp. 856-870.

https://produccioncientificaluz.org/index.php/opcion/article/view/20686

Sánchez-García, Pilar; Campos-Domínguez, Eva; Berrocal-Gonzalo, Salomé (2015). “Las funciones inalterables de los periodistas ante los perfiles multimedia emergentes". Revista latina de comunicación social, n. 70, pp. 187-208.

https://doi.org/10.4185/RLCS-2015-1042

Sánchez-García, Pilar; Marinho, Sandra (2016). “La formación digital en los programas de periodismo de España y Portugal". Andamios, v. 13, n. 31, pp. 339-361.

https://doi.org/10.29092/uacm.v13i31.439

Shuell, Thomas J. (1986). "Cognitive conceptions of learning”. Review of educational research, v. 56, n. 4, pp. 411-436. https://doi.org/10.3102/00346543056004411

Teruel-Rodríguez, Laura (2013). “Construcción colectiva del conocimiento a través de la web social y motivación del alumnado: Proyecto de innovación docente aplicado al Grado en Comunicación”. Historia y comunicación social, v. 18, n. especial noviembre, pp. 523-534.

https://doi.org/10.5209/rev_HICS.2013.v18.44258

Thurman, Neil; Walters, Anna (2012). “Live blogging. Digital journalism's pivotal platform?”. Digital journalism, v. 1, n. 1, pp. 82-101.

https://doi.org/10.1080/21670811.2012.714935

Ufarte-Ruiz, María-José; Calvo-Rubio, Luis-Mauricio; Murcia-Verdú, Francisco-José (2020). “Las tecnologías hi-tech en los grados en Periodismo. Planes de estudios, formación de los periodistas y propuestas de inserción curricular". adComunica, n. 20, pp. 43-66.

https://doi.org/10.6035/2174-0992.2020.20.3

Unizar (s.f). Programa de innovación Aprendizaje-Servicio. Universidad de Zaragoza. http://www.unizar.es/aprendizaje_servicio

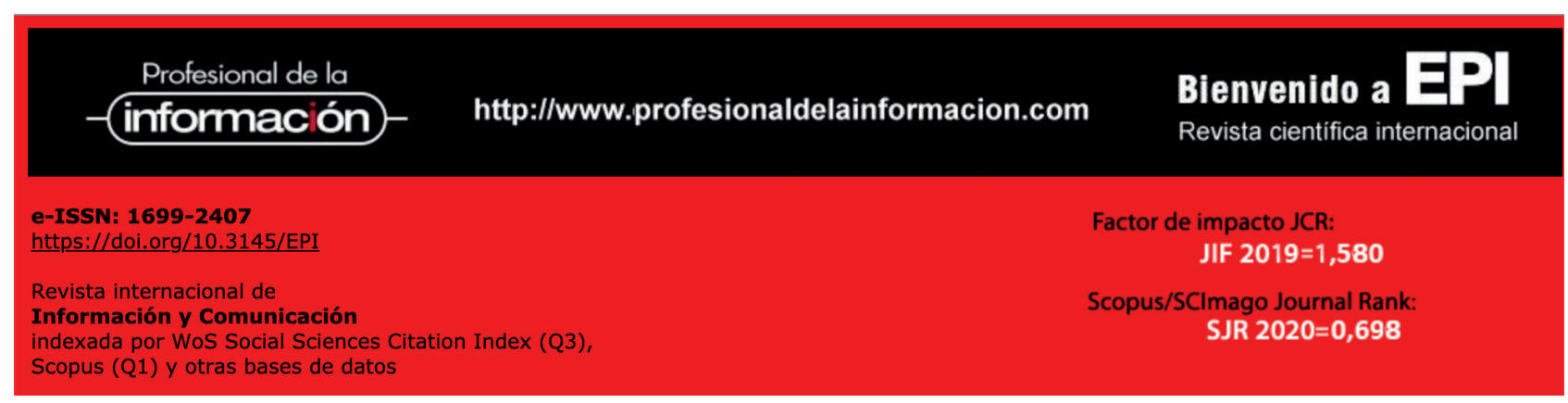

